\title{
Endophytic Enterobacter cloacae exhibits antagonistic activity against Pythium damping-off of cucumber
}

\section{Elham Ahmed Kazerooni ${ }^{1}$ Hanaa Al-Shibli ${ }^{1}$ Abbas Nasehi ${ }^{1}$ Abdullah Mohammed Al-Sadi ${ }^{*}$ (it)}

${ }^{1}$ Department of Crop Sciences, College of Agricultural and Marine Sciences, Sultan Qaboos University, PO Box 34, Al-Khod 123, Oman. E-mail: alsadi@squ.edu.om. "Corresponding author.

\begin{abstract}
The study was performed to examine the potential presence of biological control agents against Pythium damping-off disease of cucumber.Examining eleven bacterial strains isolated from acid lime roots and rhizosphere soil showed that the bacterial strain RB1 was the most efficient in suppressing mycelial growth of P. aphanidermatum, producing an inhibition zone of $5 \mathrm{~mm}$. Scanning electron microscopy study of the mycelia at the interaction zone showed that the pathogen hyphae were deformed and shriveled by the bacterial strain.In pot experiments, pretreatment with the RB1 bacterial strain reduced disease incidence significantly by $63 \%$.The bacterial strain did not exhibit any negative significant effects on cucumber growth (plant height and root dry weight) in comparison with untreated control under growth chamber conditions. Molecular identification of strain RB1 based on the $16 \mathrm{~S} r R N A$ gene revealed that it is Enterobacter cloacae. Findings from this study suggested that E. cloacae has a potential to be used as a biocontrol agent for suppressingcucumber damping-off disease caused by P. aphanidermatum. This is the first report of the antagonistic activity of E. cloacae against P. aphanidermatum-induced damping-off of cucumber. Key words: oomycetes, antagonism, biocontrol agent, endophytic bacteria.
\end{abstract}

\section{Enterobacter cloacae endofítica exibe atividade antagonista contra a podridão de pepino causada por Pythium}

\begin{abstract}
RESUMO: $O$ estudo foi realizado para examinar a presença potencial de agentes no controle biológico da doença do apodrecimento do pepino causado por Pythium. Examinando onze cepas bacterianas isoladas de raizes de cal ácida e solo da rizosfera mostraram que a cepa bacteriana RBI foi a mais eficiente na supressão do crescimento micelial de P. aphanidermatum, produzindo uma zona de inibição de 5 mm. $O$ estudo de microscopia eletrônica de varredura dos micélios na zona de interação mostrou que as hifas do patógeno foram deformadas e enrugadas pela cepa bacteriana. Em experimentos com vasos, o pré-tratamento com a cepa bacteriana RB1 reduziu significativamente a incidência da doença em $63 \%$. A cepa bacteriana não exibiu nenhum efeito negativo. Efeitos significativos no crescimento do pepino (altura da planta e peso seco da raiz), em comparação com o controle não tratado sob condições da câmara de crescimento. A identificação molecular da cepa RB1 com base no gene $16 S$ rRNA revelou que é a Enterobacter cloacae. Os resultados deste estudo sugerem que E. cloacae tem potencial para ser usado como agente de biocontrole para suprimir a doença da podridão de pepino causada por P. aphanidermatum. Este é o primeiro relato da atividade antagônica de E. cloacae contra o amortecimento induzido por P. aphanidermatum de pepino.

Palavras-chave: oomycetes, antagonismo, agente de biocontrole, bactérias endofiticas.
\end{abstract}

Cucumber (Cucumis sativus L.) is a widely cultivated and economically important vegetable crop. High value cucumber cultivars are cultivated under controlled environments. In Oman, the majority of greenhouses $(\geq 90 \%)$ are used for cucumber cultivation. Cucumber cultivation is usually in soil, with some farmers moving towards the use of hydroponics system (AL-SADI et al., 2011).

Damping-off disease is as a serious and worldwide problem on numerous agricultural and horticultural crops in fields, greenhouses, gardens, nurseries and forests. Various pathogenic oomycetes (Pythium and Phytophthora) and fungi (Fusarium and Rhizoctonia) have been reported as causal agents of damping-off (LOPEZ et al., 2018; ZHAO et al., 2019). Pythium aphanidermatum is one of the most common causes of damping-off disease, causing 25$75 \%$ cucumber seedling losses in Oman (AL-SADI et al., 2012).Management strategies in Oman rely on the use of mefenoxam, hymexazole, and propamocarb 
(AL-BALUSHI et al., 2018). However, application of these fungicides in large amounts can lead to reduction of their efficacy and building up of resistance in the fungal pathogens (MATIĆ et al., 2019).

Endophytic bacteria are plant associated microorganisms that reside in plant internal tissues without causing negative effects in their host (RYAN et al., 2008). Bacterial microorganisms including Streptomyces spp., Serratia spp., and Pseudomonas spp. and Enterobacter spp. have been efficiently used as potential biocontrol agents against Pythium damping-off (LI et al., 2007; AL-HINAI et al., 2010; ROBERTS et al., 2011). The origin of most of the bacterial strains were either soil or vegetable crops.

In Oman, Citrus has been grown for centuries. Studies have shown that citrus roots have high endophytic bacterial diversity (TORRES et al., 2008), some of which can be used as antagonists (KALAI-GRAMI et al., 2014). However, no reports exist on the isolation of antagonistic endophytic bacteria citrus against Pythium damping-off of cucumber. The present study evaluated the antagonistic activity of endophytic and rhizospheric bacteria associated with acid lime (Citrus aurantifolia L.) against $P$. aphanidermatum, the cause of dampingoff disease of cucumber.

Intact root systems (secondary roots) were taken from the rhizosphere of acid lime by excavating them to a depth of $15-30 \mathrm{~cm}$. In addition, rhizosphere soil samples within $5 \mathrm{~mm}$ of the secondary roots were taken from three plots around each tree and homogenized thoroughly. The soil samples were sandy, with $8.1 \mathrm{pH}, 2.9 \mathrm{~m} \mathrm{~S}$ electrical conductivity, $5.8 \%$ inorganic carbon, $2.3 \%$ organic carbon, $0.08 \%$ nitrogen, $0.09 \mathrm{mg} \mathrm{kg}^{-1}$ phosphorus and $26.8 \mathrm{mg} \mathrm{kg}^{-1}$ potassium. All samples were wrapped in sterile plastic bags and kept at $10^{\circ} \mathrm{C}$ in anincubator.

Soil bacteria were isolated based on the serial dilution method. The isolation petri plates were sealed with parafilm before incubation at 28 ${ }^{\circ} \mathrm{C}$ (AL-SADI et al., 2016). Morphologically welldefined bacterial colonies on the surface of plate were selected and transferred to new plates. Isolations were also conducted from acid lime roots. After surface disinfection, the root samples were dried under a laminar flow, followed by crushing them aseptically (maceration method) in sterile PBS with sterile mortar and pestle. The root content was diluted in PBS to $10^{-3}$ to form a homogenous suspension and the suspension was streaked onto generalized nutrient medium.

A pathogenic isolate, Pythium aphanidermatum isolated from naturally infected cucumber was attained from the fungal culture collection located in the Sultan Qaboos University (AL-SADI, 2012). An initial screening assay was conducted for 11 bacterial strains to evaluate their antagonistic activity against Pythium aphanidermatum. The assay was carried out as explained by KAZEROONI et al. (2019) except for using afilter paper disc containing bacterial suspension (about $5 \mathrm{~mm}$ in diameter) that was placed at the other end of the petri dish. Then $10 \mu$ of the bacterial strain suspension $(0.4 \mathrm{McF})$ was placed on filter paper disks. Plates without antagonistic bacteria were considered as controls. The petri dishes were incubated at $28^{\circ} \mathrm{C}$ in upright position to avoid losing or movement of the bacterial suspension. The size of the inhibition zone around each filter paper disk (up to the growth of the Pythium) was recorded in millimeters $(\mathrm{mm})$. The experiment was carried out three times with three replications to confirm the activity of the bacterial strains.

The most effective strain from the previous test was used in further studies. Morphological and ultrastructural changes of $P$. aphanidermatum under the effect of RB1 were screened and studied using a scanning electron microscope (SEM, INSTUMENT JSE- 5600). Pathogen hyphal tips were observed to identify the morphological differences between $P$. aphanidermatum hypha near the inhibition zone with RB1 and untreated $P$. aphanidermatum grown in PDA as control. Preparation of samples for the electron microscope was done as described by GOLDSTEIN et al. (2018).

Potting mix was autoclaved and sterilized two times at $24 \mathrm{~h}$ intervals, at $121^{\circ} \mathrm{C}(15 \mathrm{psi}, 20 \mathrm{~min})$. The experiment was conducted in $10-\mathrm{cm}$ diameter pots using three replicates per treatment/control. A one-day old bacterial suspension $(20 \mathrm{ml})$ was mixed with sterilized peat moss. Two control pots were prepared for the experiment: one without bacterial strains, and the other one with nutrient broth (without bacteria). Six disinfected cucumber seeds were sown in sufficient amount of sterilized potting mix in each pot. Incubation was at $27{ }^{\circ} \mathrm{C}$ and $70 \% \mathrm{RH}$ for 7 days. The experiment was repeated two times. The length of roots and shoots were recorded. In order to determine dry weight, cucumber seedlings were dried at $60-65{ }^{\circ} \mathrm{C}$ for 24 hours. Then the weight of each seedling was recorded.

The experiment was conducted under growth chamber conditions of $27^{\circ} \mathrm{C}$ and $70 \%$ RH for 7 days. Bacterial treatment suspension $(20 \mathrm{ml})$ was mixed with $600 \mathrm{~g}$ of sterilized potting mix. Then, a 90-mm PDA plate culture of $P$. aphanidermatum grown for 3 days was placed on the top of the 
sterilized potting mix. The remaining $200 \mathrm{~g}$ of the sterilized potting-antagonist mix was added on top of the pathogen culture. Pots inoculated with Pythium alone and pots mixed with nutrient broth alone served as controls. Untreated control pots (sterile potting mix alone) were also maintained. Survival percentage of the cucumber seedlings was determined in each pot. $P$. aphanidermatum was re-isolated from seedlings developing damping-off symptoms. Differences among treatments were analyzed using Tukey's Studentized range test (SAS v.8.)

The antagonistic bacterial strain (RB1) was identified using sequences the 16S rRNA gene. DNA was extracted in $1000 \mu \mathrm{L}$ extraction buffer as explained by AL-SADI et al. (2016). Polymerase chain reaction (PCR) was done using the $27 \mathrm{~F}$ and $1492 \mathrm{R}$ primers, with the PCR mixture been according to AL-SADI et al. (2016) while PCR conditions were according to FRANK et al. (2008). Sequencing was done at Macrogen Inc., Korea. A maximum likelihood analysis method was carried out using raxml GUI v.1.3 (SILVESTRO \& MICHALAK, 2012).
In vitro screening of the bacterial strains revealed that one strain was efficient at inhibiting the growth of $P$. aphanidermatum. Strain RB1 suppressed the mycelial growth of Pythium, producing an inhibition zone of $5 \mathrm{~mm}$. Scanning electron microscope (SEM) studies of the interaction zone of RB1 bacterial strain with Pythium aphanidermatum showed deformed pathogen hyphae including wrinkle, distortion, shrinkage and degeneration (Figure 1). On the contrary, pathogen hyphae from the control plate looked intact (Figure 1).

Inoculation of cucumber seedlings with the antagonistic bacterium RB1 did not produce any negative effects on the root length, shoot length or dry weight of cucumber (Figure 2). Inoculation of cucumber with $P$. aphanidermatum reduced the survival of cucumber to $27 \%$ within 7 days of inoculation. However, treatment of Pythium-infested pots with RB1 significantly increased the survival of cucumber seedlings to $73 \%$ when compared with the control $(90 \%)$ or to pots receiving media $(80 \%)$ (Figure 3; $\mathrm{P} \leq 0.05$ ).Thus, RB1 significantly increased the survival rate of cucumber seedlings from $27 \%$ to

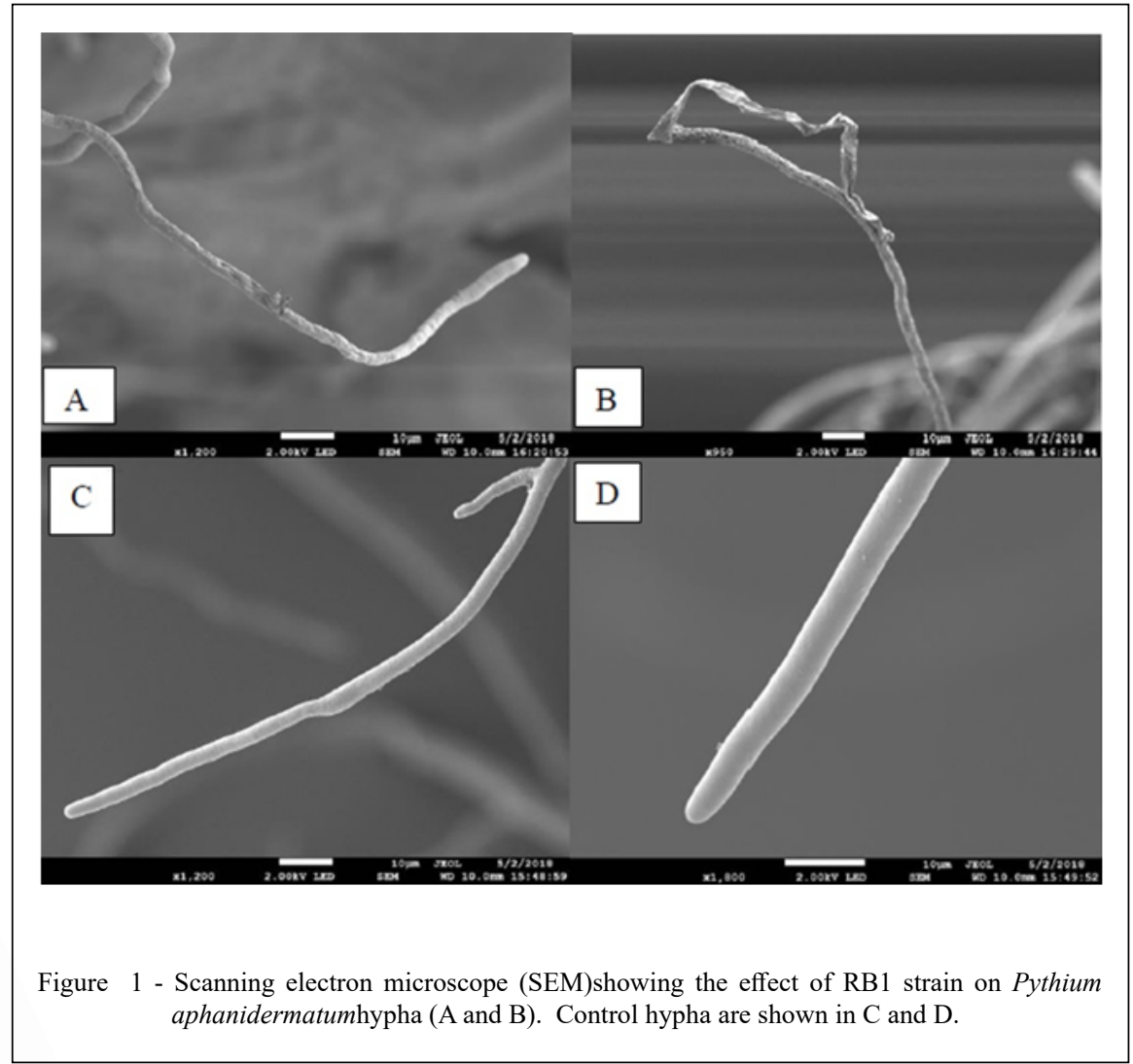

Ciência Rural, v.50, n.8, 2020. 


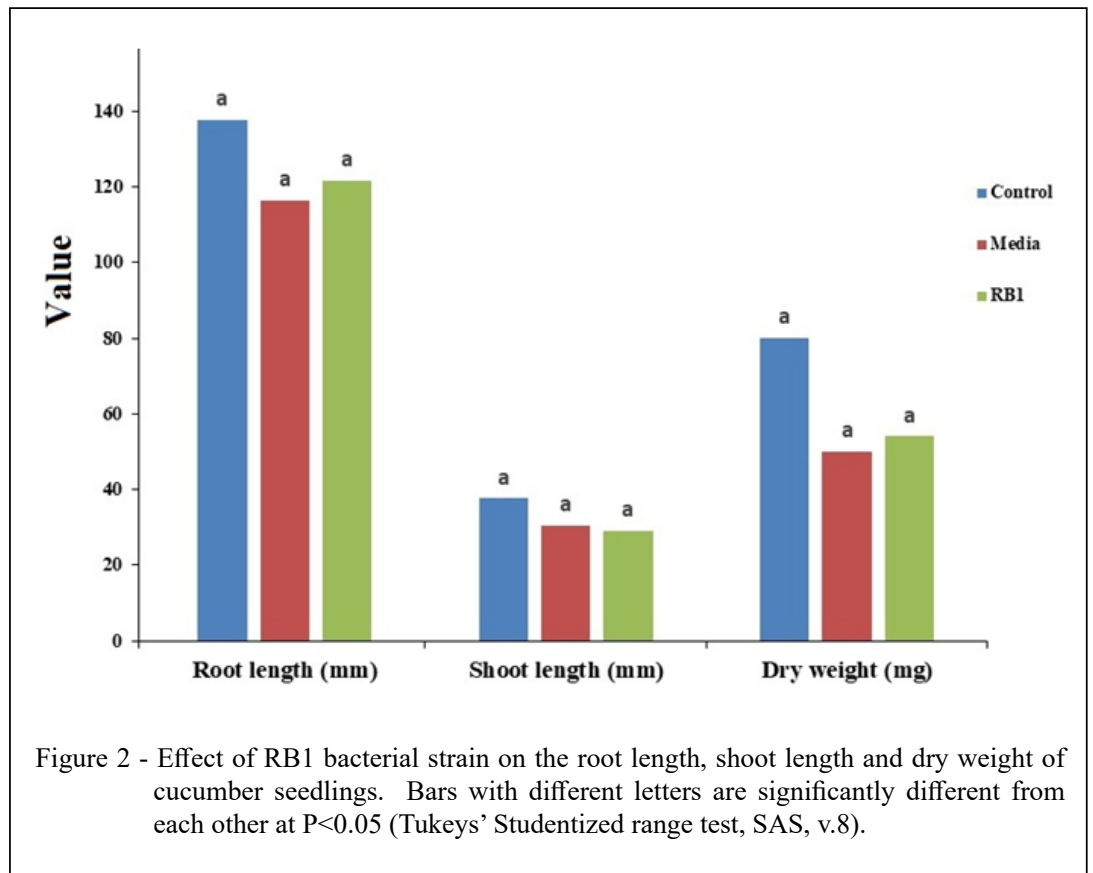

$173 \%$ (Figure 3). P. aphanidermatum was re-isolated

2 from the diseased cucumber seedlings. Based on

3 sequence analysis, the antagonistic bacterial strain

4 RB1 was identified as Enterobacter cloacae. The sequence of the strain was deposited in GenBank 1 under the accession no. MK256309 (Figure 4). 2

Our scanning electron microscope results 3 disclosed structural deformation of pathogen hyphae 4

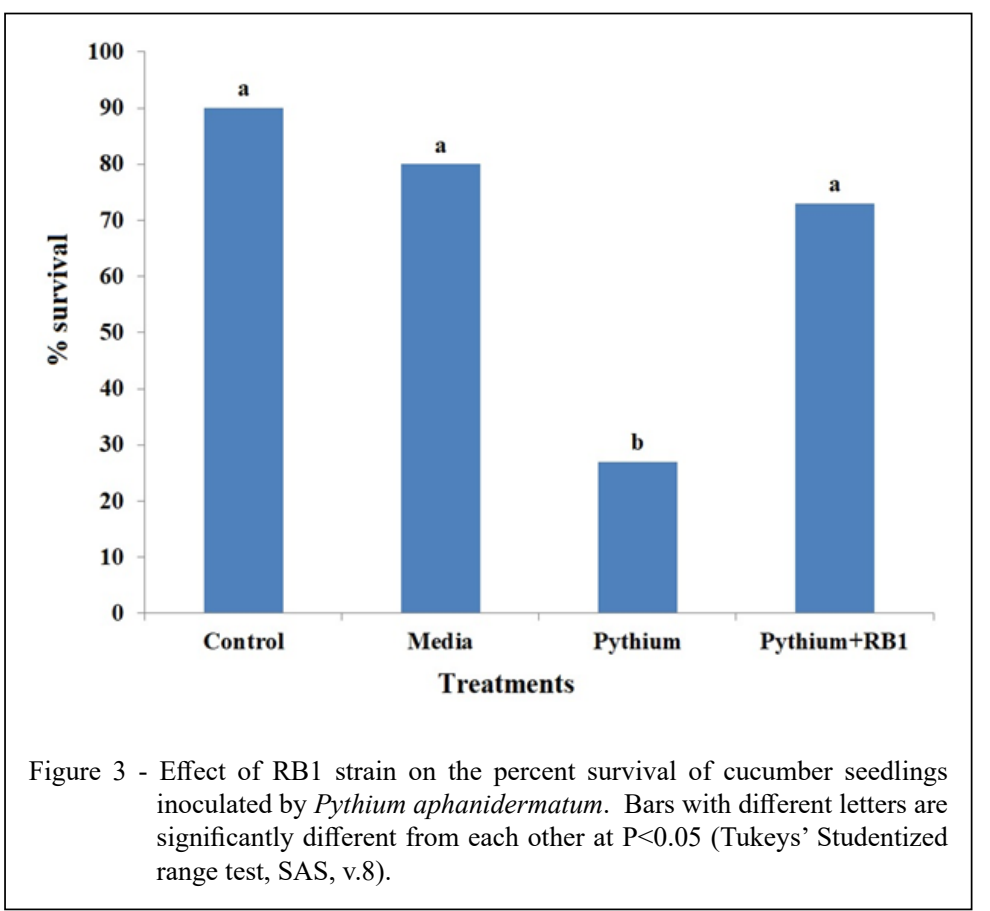

Ciência Rural, v.50, n.8, 2020. 
at the inhibition zone. $P$. aphanidermatum hyphae showed deformations, evident of the effect of the bacterial strain on its structure. Endophytic bacteria are capable of suppressing plant pathogenic fungi by producing antimicrobial compounds. These compounds can cause deformation and lysis of mycelia (YUAN et al., 2012). Our bacterial strain was identified as E. cloacae. Future studies may be required to assess the mode of action of this bacterial strain against $P$. aphanidermatum.

Growth chamber results demonstrated that E. cloacaeshowed considerable disease reduction compared to untreated control. E. cloacae appears to possess biocontrol potential against damping-off caused by $P$. aphanidermatum. The biocontrol potential of E. cloacae has been reported in other crops and pathogens, including its use against cucumber wilt (Fusariumoxysporum f. sp. cucumerinum) (SNEH et al., 1984), turfgrass blight (Pythium aphanidermatum) (NELSON \& CRAFT, 1992), and dollar spot of turf (Sclerotinia homoeocarpa) (NELSON \& CRAFT, 1991). Our study appears to be the first report of the effective use of $E$. cloacae in suppressing $P$. aphanidermatum and Pythium-induced damping-off in cucumber. Future studies should investigate the mechanisms associated with this suppression.

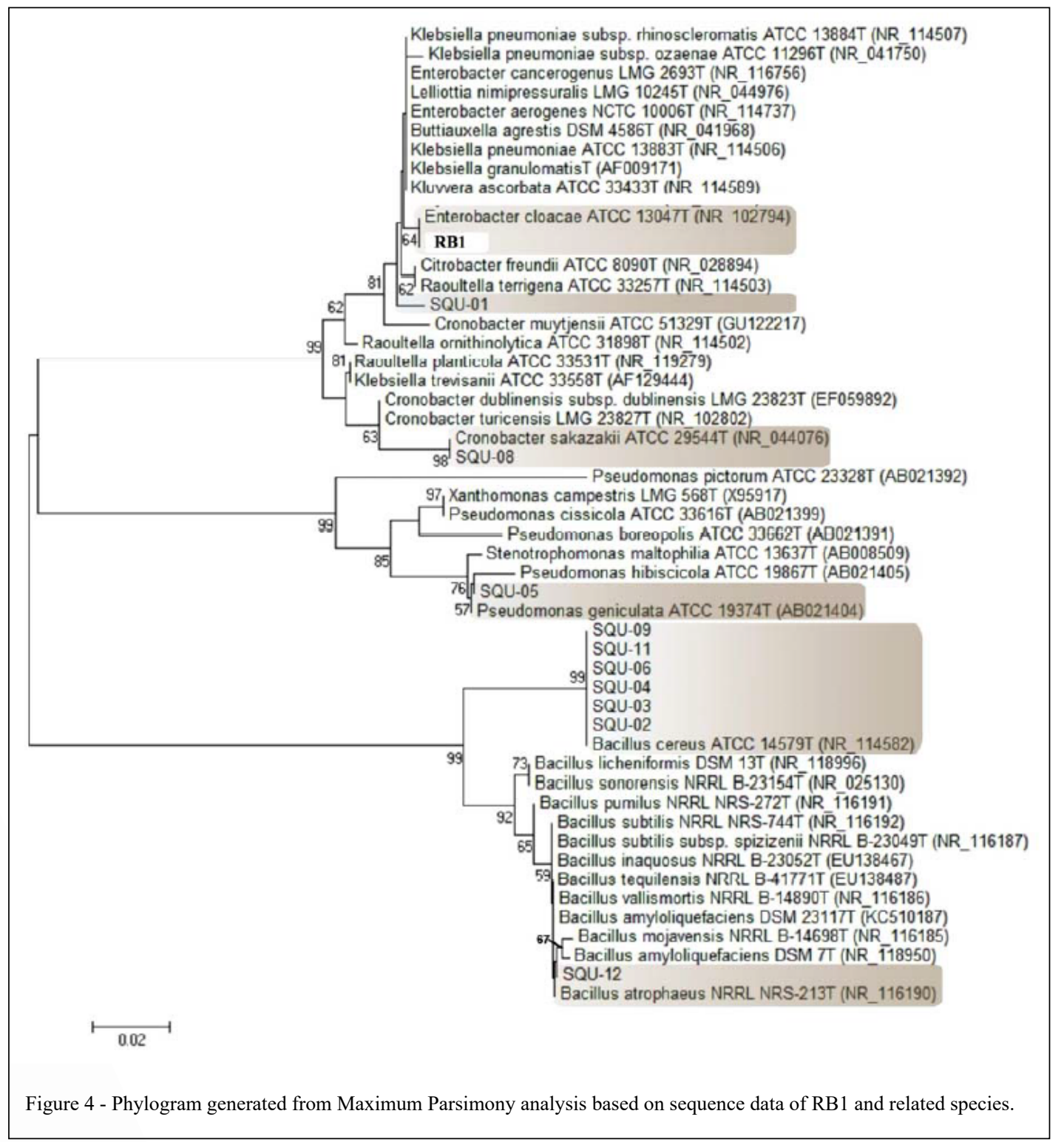

Ciência Rural, v.50, n.8, 2020. 


\section{ACKNOWLEDGMENTS}

Thanks to Sultan Qaboos University and Oman Animal and Plant Genetic Resources Center for financial support of the study through the projects EG/AGR/CROP/16/01, CR/AGR/ CROP/19/01 and SR/SCI/CHEM/19/01.

\section{DECLARATION OF CONFLICT OF INTERESTS}

The authors declare no conflict of interest. The founding sponsors had no role in the design of the study; in the collection, analyses, or interpretation of data; in the writing of the manuscript, and in the decision to publish the results.

\section{AUTHORS' CONTRIBUTIONS}

EA and HA conducted the experiments, and EA, HA, AN and AMA analyzed results and wrote the manuscript.

\section{REFERENCES}

AL-BALUSHI, Z. M., et al. Development of resistance to hymexazol among Pythium species in cucumber greenhouses in Oman. Plant Disease, v.102, n.1, p.202-208, 2018. Available from: $\quad<$ https://www.scopus.com/inward/record.uri?eid=2-s2.085038854052\&doi=10.1094\%2fPDIS-11-16-1680-RE\&partner ID $=40 \& m d 5=a f b c 5 c 47 a 415 b 0 b f 8 b b 2 f b d c e 494 f 12 f>$. Accessed: Dec. 30, 2019. doi: 10.1094/PDIS-11-16-1680-RE.

AL-HINAI, A. H., et al. Isolation and characterization of Pseudomonas aeruginosa with antagonistic activity against Pythium aphanidermatum. Journal of Plant Pathology, v.92, n.3, p.653-660, 2010. Available from: <https://www.scopus.com/ inward/record.uri?eid=2-s2.0-78650721925\&partnerID $=40 \& \mathrm{~m}$ d5 $=497 d 07 d 69 c b 1 c 01 a 0 f 244 b 8 \mathrm{e} 923 a 765 e>$. Accessed: Dec. 30, 2019. doi: 10.4454/jpp.v92i3.310.

AL-SADI, A. M. Efficacy of mefenoxam is affected by a lag period between application and inactivation of Pythium species. Phytopathologia Mediterranea, v.51, n.2, p.292-297, 2012. Available from: <https://www.scopus.com/inward/record. uri?eid=2-s2.0-84871552297\& partnerID $=40 \& \mathrm{md} 5=9 \mathrm{ebe} 807$ 37bdfde67e3de59ea108f942d>. Accessed: Dec. 27, 2019. doi: 10.14601/Phytopathol Mediterr-9625.

AL-SADI, A. M., et al. Analysis of diversity in Pythium aphanidermatum populations from a single greenhouse reveals phenotypic and genotypic changes over 2006 to 2011. Plant Disease, v.96, n.6, p.852-858, 2012. Available from: $<$ https://www. scopus.com/inward/record.uri?eid=2-s2.0-84930476626\&partner $\mathrm{ID}=40 \& \mathrm{md} 5=84 \mathrm{a} 42 \mathrm{fabff} 2 \mathrm{bf} 55 \mathrm{fbe} 8614360171251 \mathrm{~b}>$. Accessed: Dec. 30, 2019. doi: 10.1094/pdis-07-11-0624.

AL-SADI, A. M., et al. Etiology and characterization of cucumber vine decline in Oman. Crop Protection, v.30, n.2, p.192-197, 2011. Available from: <https://www.scopus.com/inward/record. uri?eid=2-s2.0-78650730532\&doi=10.1016\%2fj.cropro.2010.10. 013\&partnerID $=40 \&$ md5 $=$ eabd0cc1d7ce9f6fef3eb309ff56223d $>$. Accessed: Dec. 30, 2019. doi: 10.1016/j.cropro.2010.10.013.

AL-SADI, A. M., et al. Analysis of bacterial communities associated with potting media. SpringerPlus, v.5, n.1, p.1-5,
2016. Available from: <https://www.scopus.com/inward/record. uri? eid $=2-s 2.0-84955622323 \&$ partnerID $=40 \& \mathrm{md} 5=2 \mathrm{fb} 9536985 \mathrm{a}$ 2d6eaa34af09097e2ecf6>. Accessed: Dec. 30, 2019. doi: 10.1186/ s40064-016-1729-0.

FRANK, J. A., et al. Critical evaluation of two primers commonly used for amplification of bacterial 16S rRNA genes. Applied and Environmental Microbiology, v.74, n.8, p.2461-2470, 2008. Available from: <https://www.scopus.com/ inward/record.uri?eid=2-s2.0-42349100152\&doi $=10.1128 \%$ 2fAEM.02272-07\&partnerID=40\&md5=2da $158 \mathrm{f} 466 \mathrm{c} 2 \mathrm{~cd} 88$ ee0f5f1f3fb512b8>. Accessed: Dec. 27, 2019. doi: 10.1128/ AEM.02272-07.

GOLDSTEIN, J. I., et al. Scanning electron microscopy and X-ray microanalysis. New York: Springer-Verlag. 2018. 1-550p. (Scanning Electron Microscopy and X-ray Microanalysis). Available from: $<$ https://www.scopus.com/inward/record. uri?eid=2-s2.0-85042426258\&doi=10.1007\%2f978-1-4939-66769\&partnerID $=40 \&$ md5 $=$ baf5ecb7029a696fb10476253f12d992>. Accessed: Dec. 27, 2019. doi: 10.1007/978-1-4939-6676-9.

KALAI-GRAMI, L., et al. Isolation and characterization of putative endophytic bacteria antagonistic to Phoma tracheiphila and Verticillium albo-atrum. Applied Biochemistry and Biotechnology, v.174, n.1, p.365-375, 2014. Available from: $<$ https://www.scopus.com/inward/record.uri?eid=2-s2.0$84929129108 \&$ doi $=10.1007 \% 2 \mathrm{fs} 12010-014-1062-4 \&$ partnerID $=$ 40\&md5=538f358dd74e56fc34c8d5dcecc1bdd3 $>$. Accessed: Dec. 30, 2019. doi: 10.1007/s12010-014-1062-4.

KAZEROONI, E. A., et al. Talaromyces pinophilus inhibits Pythium and Rhizoctonia-induced damping-off of cucumber. Journal of Plant Pathology, v.101, p.377-383, 2019. Available from: <https://doi.org/10.1007/s42161-018-0186-8>. Accessed: Dec. 30, 2019. doi: 10.1007/s42161-018-0186-8.

LI, B., et al. Biocontrol of Pythium damping-off in cucumber by arbuscular mycorrhiza-associated bacteria from the genus Paenibacillus. BioControl, v.52, n.6, p.863-875, 2007. Available from: <https://doi.org/10.1007/s10526-007-9076-2>. Accessed. doi: 10.1007/s10526-007-9076-2.

LOPEZ,P., etal.Firstreport of Pythiummyriotylum causing dampingoff of Amaranthus tricolor in Florida. Plant Disease, v.102, n.4, p.828, 2018. Available from: <https://www.scopus.com/inward/ record.uri?eid=2-s2.0-85044235300\&doi=10.1094\%2fPDIS07-17-1132-PDN\&partnerID=40\&md5=a0082995b5638b7c65 2708a3653a192f>. Accessed: Dec. 28, 2019. doi: 10.1094/PDIS07-17-1132-PDN.

MATIĆ, S., et al. Differentiation of Pythium spp. from vegetable crops with molecular markers and sensitivity to azoxystrobin and mefenoxam. Pest Management Science, v.75, n.2, p.356-365, 2019. Available from: <https://www.scopus.com/inward/record. uri?eid=2-s2.0-85052788364\&doi $=10.1002 \% 2 \mathrm{fps} .5119 \&$ partnerI $\mathrm{D}=40 \& \mathrm{md} 5=83 \mathrm{dc} 745644 \mathrm{a} 862 \mathrm{ae} 2 \mathrm{ae} 7 \mathrm{e} 41 \mathrm{e} 3 \mathrm{edd} 3 \mathrm{e} 68>$. Accessed: Dec. 30, 2019. doi: 10.1002/ps.5119.

NELSON, E. B.; CRAFT, C. M. Introduction and establishment of strains of Enterobacter cloacae in golf course turf for the biological control of dollar spot. Plant Disease, v.75, p.510-514, 1991. Available from: <https://www.apsnet.org/ publications/PlantDisease/BackIssues/Documents/1991Articles/ PlantDisease75n05 510.PDF $>$. Accessed: Dec. 25, 2019. doi: 10.1094/PD-75-0510. 
NELSON, E. B.; CRAFT, C. M. A miniaturized and rapid bioassay for the selection of soil bacteria suppressive to Pythium blight of turfgrasses. Phytopathology, v.82, p.206-210, 1992. Available from: <https://www.apsnet.org/publications/ phytopathology/backissues/Documents/1992Articles/ Phyto82n02_206.PDF $>$. Accessed: Dec. 26, 2019. doi: 10.1094/ Phyto-82-206.

ROBERTS, D. P., et al. Mutation of a $\operatorname{degS}$ homologue in Enterobacter cloacae decreases colonization and biological control of damping-off on cucumber. Phytopathology, v.101, n.2, p.271280, 2011. Available from: <https://www.scopus.com/inward/ record.uri?eid=2-s2.0-79952275925\&doi $=10.1094 \% 2 \mathrm{fPHYTO}$ 03-10-0076\& partnerID $=40 \& \mathrm{md} 5=479 \mathrm{~d} 7933$ ef $8 \mathrm{~d} 958 \mathrm{ae} 74$ 549c20d565292>. Accessed: Dec. 25, 2019. doi: 10.1094/ PHYTO-03-10-0076.

RYAN, R. P., et al. Bacterial endophytes: Recent developments and applications. FEMS Microbiology Letters, v.278, n.1, p.19, 2008. Available from: <https://www.scopus.com/inward/ record.uri?eid=2-s2.0-36749048735\&doi $=10.1111 \% 2 \mathrm{fj} .1574$ 6968.2007.00918.x\&partnerID $=40 \& \mathrm{md} 5=7102 \mathrm{aa} 27 \mathrm{bbc6e} 6 \mathrm{a} 86 \mathrm{~d} 7$ 703fd357b4d29>. Accessed: Dec. 26, 2019. doi: 10.1111/j.15746968.2007.00918.x.

SILVESTRO, D.; MICHALAK, I. RaxmlGUI: a graphical frontend for RAxML. Organisms Diversity and Evolution, v.12, n.4, p.335-337, 2012. Available from: <https://doi.org/10.1007/ s13127-011-0056-0>. Accessed: Dec. 30, 2019. doi: 10.1007/ s13127-011-0056-0.
SNEH, B., et al. Chlamydospore germination of Fusarium oxysporum f. sp. cucumerinum as affected by fluorescent and lytic bacteria from a Fusarium-suppressive soil. Phytopathology, v.74, p.1115-1124, 1984. Available from: <https://www.apsnet.org/ publications/phytopathology/backissues/Documents/1984Articles/ Phyto74n09_1115.PDF>. Accessed: Dec. 26, 2019. doi: 10.1094/ Phyto-74-1115.

TORRES, A. R., et al. Diversity of endophytic enterobacteria associated with different host plants. Journal of Microbiology, v.46, n.4, p.373-379, 2008. Available from: $<$ https://www.scopus.com/inward/record.uri? eid=2-s2.0$56149088301 \&$ doi $=10.1007 \% 2 \mathrm{fs} 12275-007-0165-9 \&$ partnerID= 40\&md5=8c0da83e64f40d8260c1899f087d2f94>. Accessed: Dec. 30, 2019. doi: 10.1007/s12275-007-0165-9.

YUAN, J., et al. Antifungal activity of Bacillus amyloliquefaciens NJN-6 volatile compounds against Fusarium oxysporum f. sp. cubense. Applied and Environmental Microbiology, v.78, n.16, p.5942, 2012. Available from: <http://aem.asm.org/ content/78/16/5942.abstract $>$. Accessed: Dec. 28, 2019. doi: 10.1128/AEM.01357-12.

ZHAO, C., et al. Anastomosis group and pathogenicity of Rhizoctonia spp. associated with seedling damping-off of sugar beet in China. European Journal of Plant Pathology, v.153, n.3, p.869-878, 2019. Available from: <https://www.scopus.com/inward/record.uri?eid=2s2.0-85053525376\&doi=10.1007\%2fs10658-018-1603-8\&partnerID $=40 \& \mathrm{md} 5=\mathrm{a} 0 \mathrm{e} 12 \mathrm{~d} 916 \mathrm{bedff5e} 18 \mathrm{f} 2 \mathrm{~d} 10 \mathrm{ddf} 7 \mathrm{dbcda}>$. Accessed: Dec. 28, 2019. doi: 10.1007/s10658-018-1603-8. 